\title{
Challenges in Doctoral Research Project Management: A Comparative Study
}

\author{
Reuven Katz \\ Technion, Israel Institute of Technology, Haifa, Israel
}

reuvenk@technion.ac.il

\begin{abstract}
This paper presents quantitative results of a comparative study evaluating the management skills of doctoral candidates working toward a $\mathrm{PhD}$ and additional information related to their lifestyles. We conducted a survey among enrolled doctoral candidates at five universities in Israel and three technological universities in Western Europe. 1013 Israeli candidates and 457 Western European candidates replied to our survey. In our analysis, we compared the answers of Israeli Science and Engineering candidates to those of Social Sciences and Humanities candidates; in addition, we compared the answers of Israeli Science and Engineering students to their Western European peers. Our analysis focused on finding significant patterns by comparing these groups of students. In order to identify such patterns, we analyzed each question using the Pearson chi-square test. The current study's main finding is that the majority of candidates, regardless of their chosen academic field or the region where they study, have no training or expertise in managing a doctoral research project. Based on these findings, we suggest that all doctoral candidates be taught basic research-project management. We believe that such training will provide them with a powerful tool for better managing their research as they advance towards successful completion of their doctorate.
\end{abstract}

Key words: Doctoral research management, Adviser-candidate relationship, Doctoral education

\section{Introduction}

A research project is a temporary undertaking, with a defined beginning and end, designed to produce a unique result despite being constrained by limited time and/or funding. The temporary nature of these projects requires project management skills for meeting prescribed constraints of quality, time, scope, and budget. These management skills are different from skills needed for managing a "business-as-usual" operation. The process of working towards a doctoral degree as a research project is widely recognized in the literature (Lauriol, 2006; Lee, 2008; Pyhältö, Vekkaila, and Keskinen, 2012) as well as by the par-

Material published as part of this publication, either on-line or in print, is copyrighted by the Informing Science Institute. Permission to make digital or paper copy of part or all of these works for personal or classroom use is granted without fee provided that the copies are not made or distributed for profit or commercial advantage AND that copies 1) bear this notice in full and 2) give the full citation on the first page. It is permissible to abstract these works so long as credit is given. To copy in all other cases or to republish or to post on a server or to redistribute to lists requires specific permission and payment of a fee. Contact Publisher@InformingScience.org to request redistribution permission. ticipating candidates.

The main objective of our research focused on identifying doctoral research management patterns. Our two main goals were to identify and compare management patterns that characterize different academic disciplines in Israeli universities and to compare management patterns of Science and Engineering candidates from Israel with those of candidates from Western Europe. In order to attain a 
broader perspectives on candidates' opinions regarding their doctoral experience, we included two additional objectives: a) to study candidates' relations with their advisers, and b) to learn about candidates' lifestyle, experiences, and feelings in relation to their doctoral research process.

Our survey uses project management terminology adjusted to the framework of doctoral studies. By analyzing candidates' replies, we can learn whether doctoral students are aware of their management challenges and if they possess the tools needed to manage a doctoral research project.

In order to conduct the research, we distributed a uniform questionnaire to doctoral candidates at five leading Israeli research universities as well as universities in three Western European countries - Italy, Portugal, and Switzerland. Following Becher's (1994) discussion of disciplinary differences within universities, we aimed to compare the opinions of students from different academic disciplines (Humanities and Social Sciences vs. Natural Sciences and Engineering). Our goal was to investigate the existence of opinion patterns across academic discipline and to possibly identify specific patterns or establish a relationship between patterns and disciplines. We were also interested in comparing opinions of doctoral students in Science and Engineering from Israel and from Western Europe. This part of the study was motivated by the fact that Israeli universities have been participating in the EU Programs for Research and Innovation. In these projects, teams of scientists and engineers from Europe and Israel work together on innovative projects. Graduate students from both places find themselves cooperating and sharing views and experiences.

Survey questionnaires were sent to all doctoral students by the graduate departments of each participating university. The results received from candidates at each university were separately analyzed. The graduate school at each participating university received a summary of their candidates' results. As interesting as these findings are, we have not included these separate results in this paper due to confidentiality concerns. Instead, we decided to present an analysis of the cumulative results received from candidates in Israel and in Western Europe, comparing them by academic field and location, as will be described below.

\section{Literature Review}

Jones (2013) examined 995 papers, written over the past 40 years, regarding issues pertaining to doctoral studies. He presented six central themes through which the management and training of doctoral students had been demonstrated: teaching, doctoral program design, writing and research, employment and career, student-supervisor relationship, and the doctoral student experience. According to Jones, four problems relating to doctoral research are commonly discussed in the literature: program attrition, supervisor relationship, supervisor quality, and social isolation.

\section{Doctoral Project Management}

The term research project is frequently used in association with doctoral research (Lauriol, 2006; Lee, 2008; Pyhältö, Vekkaila, and Keskinen, 2012). Research towards a doctorate, in all academic fields, represents a classic research project and, in fact, meets the formal definition of a research project (Project Management Institute, 2013). It has a definite starting point - the moment when a proposal is formally accepted or when the candidate passes an examination. It also has a definite end-point - when the candidate successfully defends his or her thesis during the final examination. It has an objective - the scientific contribution to the student's scientific field. It has limited resources - primarily the candidate's time and effort. Therefore, the candidate naturally becomes the Project Manager of his own research project, but in most cases, students are not aware of this fact or of the need to manage the project. In order to implement doctoral research, most candidates focus solely on performing scientific tasks, while tending to neglect management. Most candidates do not understand that during the course of doctoral studies, one has to perform two 
parallel tasks: The first and foremost task is to conduct academic studies and write a dissertation, but the other task is to plan and efficiently manage a research project (Katz, 2009).

Phillips and Pugh (2010) discuss elements of project management used for managing doctoral research. They explain how to define short-term and long-term goals of the research, how to manage time and tasks, and how to meet deadlines. The authors view the total doctoral project process as a series of tasks which lead to the progressive reduction of uncertainty. In doctoral research, as in any research project, uncertainty is high at the beginning. In planned task management, the candidate reduces the uncertainty as the project advances. McWilliam, Singh, and Taylor (2002) discuss the topic of risk management in doctoral education. Risk management is another leading element of project management. The authors discuss risk minimization in the context of the adviser-student relationship. Graves and Varna (1998) advise the students that "time is needed to identify, design and carry out the (doctoral) project" (p. 60) and go on to explain how to plan time, how to plan research phases, and how to practically create a project plan. Graves and Varna use project management terminology, stressing the significance of meeting deadlines and the importance of creating milestones along the road to a PhD. Grover (2007) stated that students are usually capable of completing a doctoral program and are usually highly motivated. A key element for success is their ability to manage their program and avoid mistakes. Grover offers the candidates a checklist to be used as an evaluation tool for those who wish to assess the progress of their doctoral study.

Project management techniques can be easily adjusted to the doctoral research domain (Katz, 2009). This may assist the candidate in planning his or her research systematically and in learning efficient methods for managing time and effort. It is important to note that most research projects conducted in the hi-tech scientific industry regularly apply project management tools (Cardinal, 2001).

\section{Relations with the Adviser}

The supervisory relationship is likely to "make or break" the doctoral candidature. A poor relationship with one's doctoral adviser will ruin a good doctoral project regardless of any or all of the other elements that may support it (Jones, 2013). Protivnak and Foss (2009) showed that collaboration between students and faculty members was an important factor for successfully completing doctoral studies. They reported that many students felt that the mentoring they received was the most helpful experience of their doctoral studies; conversely, some students had difficulty with doctoral mentoring and felt abandoned. Holbrook et al. (2014) studied initial expectations of doctoral candidates and linked them with satisfaction and the candidate's well-being, finding that a satisfied student naturally feels good as a candidate in a doctoral program. The supervisory relationship has been identified as one of the main factors influencing student satisfaction and success or disappointment (Jairam \& Kahl, 2012; Zhao, Golde, \& McCormick, 2007). Mason (2012) stated that having a collegial relationship with advisers is also critical for students' satisfaction and motivation, so these relationships should be encouraged. Published literature has identified a need for balance and support the life of doctoral students (Gardner, 2008; Lovitts, 2001). The isolation that accompanies doctoral studies must be balanced with peer or supervisor support, otherwise isolation can lead to attrition (Gardner, 2010). Therefore, good relations with the adviser were critical for the candidate's well-being and success.

The idea that students should be proactive in "managing their adviser" is presented by Grover and Thatcher (2010). Doctoral candidates who prepare in advance for meetings with their advisers, raising possible solutions to their own issues and soliciting their adviser's advice, use their time more efficiently and get better results. Gatfield (2005) presented various advisory management styles and different relationships between advisers and candidates. The advisory management model relates to the adviser's support and supervisory structure. Gatfield showed that the model 
is dynamic and changes over time as the doctoral research process advances. Gatfield suggests that apprentice advisers be given workshop training in advisory styles in order to learn how to efficiently advise doctoral students. Jones (2013) indicated that most doctoral supervisors today lack adequate supervisory capabilities and tend to largely overlook their fundamental role as mentors. Furthermore, he identified a lack of suitable training available to fill the void. Delamont, Parry, and Atkinson (1998) discuss the doctoral adviser's dilemma in striking a delicate balance between directing students and letting them be independent. Dr. Rennie, a social scientist at Rushberry, highlighted the importance of the managerial side of the supervisory task:

The main thing, in my point of view, is to know what the job is to manage the student. To be a good adviser I don't happen to believe you need to know an awful lot about the substantive field the student is doing. A good student will already have become more expert in the substantive field than the adviser. (Delamont, Parry, \& Atkinson, 1998, p. 160)

This point of view clearly expresses the importance of an adviser's managerial skills that, in some instances, may become more significant than the adviser's expertise in a specific research topic.

One of the many available references that discuss attrition in $\mathrm{PhD}$ programs suggests that the most important factor in a student's decision to continue or withdraw from a program is their relationship with the faculty adviser (Lovitts \& Nelson, 2000). A concerned faculty adviser is the person best placed to assess an individual's progress and reinforce the student's sense of selfworth. Students who complete their degrees are twice as likely to express satisfaction with their faculty advisers as students who leave the doctoral program.

\section{Goals of the Study}

The main goal of our study and the focus of this paper are to explore doctoral research management patterns, and specifically:

- To identify and compare management patterns that characterize different academic disciplines in Israel; and

- To compare management patterns of Science and Engineering candidates from Israel with those of candidates from Western Europe.

To attain a broader perspective on candidates' opinions regarding other areas pertaining to the experience of conducting the doctoral research project, we included two additional goals:

- To explore candidates' opinions about their relations with the adviser

- To collect quantitative information about candidates' lifestyle, experiences and feelings in relation to the doctoral research process.

Again, we compared answers from Israeli candidates studying in different academic disciplines, as well as from Science and Engineering candidates in Israel and Western Europe.

\section{Methodology}

We distributed a uniform questionnaire with multiple choice questions to all enrolled doctoral candidates at several universities in Israel and in three Western European countries: Italy, Portugal, and Switzerland. The graduate office at each participating university sent the questionnaire to each candidate's personal email. Students were asked to reply anonymously and submit the answers as a Google Docs file. Five leading Israeli research universities and three leading European technological universities (one in Italy, one in Portugal and one in Switzerland) participated in the study. In all, approximately 10,000 candidates received our questionnaire. The typical rate of reply from each university was $12-18 \%$. The obtained results were analyzed in order to identify 
patterns representing students' opinions about managing a doctoral research, relations with the adviser, and influence of the process on their lifestyle.

The survey included 26 questions, of which 15 were included in our analysis. The first four questions pertained to general information: the students' age at enrollment; their enrollment status i.e., internal (full-time) or external (part-time) candidates; their motivation to pursue a $\mathrm{PhD}$; and their learning habits. Each question had multiple choice answers, and the candidate was asked to select and mark one. Candidates were then asked to indicate their academic discipline, choosing one of 17 options. For Israeli universities, we decided to include in the study only academic disciplines that received more than 100 responses each. Four disciplines met this criterion: Sciences, Engineering, Social Sciences, and Humanities. Due to this criterion, we subsequently included 772 replies out of the 1013 received. As explained in the introduction, the second part of the study focused on comparing Science and Engineering candidates from Israel with those from Western European countries. We included 360 answers from Sciences and Engineering students in Western Europe out of 457 answers received. These 360 answers were compared with 466 answers from Israeli Science and Engineering students.

The data for each of the 15 questions is presented in Tables 1-15. Each table presents one question and the multiple choice answers, as stated in the questionnaire. Observing the collected data and analyzing the survey results, we decided to further aggregate the information as it related to the academic discipline. We observed that there were different patterns characterizing answers from candidates enrolled in "Hard Sciences" disciplines (namely Sciences and Engineering, $\mathbf{S \& E}$ ) and from candidates enrolled in "Soft Sciences" disciplines (Social Sciences and Humanities, SS\&H). We did not include invalid answers in the statistical analysis; these are denoted in the tables as "not specified." In order to analyze the typical pattern of students' answers to each question, we applied Pearson's chi-square test. Using this test, we could clearly define a "similar pattern" $(p>0.05)$ indicating that there was no significant difference between answers from compared populations (academic disciplines or countries).

\section{Results and Analysis}

Survey results are presented in four categories. Each category represents a cluster of survey questions:

1. General information.

2. Managerial skills.

3. Relations with the adviser.

4. Summary of questions about candidates' experiences and feelings during the doctoral studies.

For each answer in the four categories, we decided to analyze and compare the results for two main groups of students:

a) Israeli S\&E and SS\&H students.

b) $\mathrm{S} \& \mathrm{E}$ candidates from Israel and from Western Europe.

\section{General Information}

Q1: Are you enrolled in the PhD program as a full-time doctoral student?

Examining Table 1, it is clear that more SS\&H students were enrolled in the $\mathrm{PhD}$ programs as part-time, external students. 
In Israel, $92.62 \%$ of S\&E candidates were enrolled as full-time students while only $68.87 \%$ of SS\&H candidates were full-time students. There was a significant difference in the enrollment pattern between the two academic fields $\left(\mathrm{DF}=1, \chi^{2}=73.720, \mathrm{p}<.0001\right)$.

In contrast, $91.36 \%$ of S\&E candidates in Western Europe were enrolled as full-time students. The pattern was similar as there was no significant difference between Israel and Western Europe $\left(\mathrm{DF}=1, \chi^{2}=0.440, \mathrm{p}=.510\right)$.

\begin{tabular}{|l|c|c|c|c|c|c|c|c|}
\hline \multicolumn{7}{|c|}{ Table 1: Are you enrolled in the PhD program as a full time doctoral student? } \\
\hline & \multicolumn{3}{|c|}{ Israel } & \multicolumn{3}{c|}{ Western Europe } \\
\hline & Total & $\begin{array}{c}\text { Social } \\
\text { Scienc- } \\
\text { es }\end{array}$ & $\begin{array}{c}\text { Humanitie } \\
\text { s }\end{array}$ & Sci. & Eng. & Sci. & Eng. & Total \\
\cline { 2 - 10 } & $\begin{array}{c}\mathrm{n}=101 \\
3\end{array}$ & $\mathrm{n}=153$ & $\mathrm{n}=153$ & $\mathrm{n}=344$ & $\mathrm{n}=122$ & $\mathrm{n}=103$ & $\mathrm{n}=257$ & $\mathrm{n}=457$ \\
\hline $\begin{array}{l}\text { I am an internal, full } \\
\text { time doctoral student }\end{array}$ & $76.5 \%$ & $64.7 \%$ & $71.2 \%$ & $95.6 \%$ & $80.3 \%$ & $98.1 \%$ & $88.3 \%$ & $\begin{array}{c}91.4 \\
\%\end{array}$ \\
\hline $\begin{array}{l}\text { I am an external, part } \\
\text { time doctoral student }\end{array}$ & $22.5 \%$ & $34.0 \%$ & $27.5 \%$ & $3.2 \%$ & $18.9 \%$ & $1.9 \%$ & $11.3 \%$ & $8.4 \%$ \\
\hline Not Specified & $1.0 \%$ & $1.3 \%$ & $1.3 \%$ & $1.2 \%$ & $0.8 \%$ & $0.0 \%$ & $0.4 \%$ & $0.2 \%$ \\
\hline
\end{tabular}

\section{Q2: At what age did you start your doctoral program?}

Western European students started their doctoral studies at a younger age than Israeli students (Table 2).

In Israel, $4.58 \%$ of S\&E students started their doctoral program when over 40 years old, while $25.99 \%$ of SS\&H candidates began at that age, presenting a significant difference in the pattern $\left(\mathrm{DF}=1, \chi^{2}=73.62, \mathrm{p}<.0001\right)$.

In Israel, $52.94 \%$ of S\&E students started the program at under 29 years, while in Western Europe this was $86.20 \%$, presenting a significant difference in the pattern $\left(\mathrm{DF}=1, \chi^{2}=88.86\right.$, $\mathrm{p}<.0001)$.

\begin{tabular}{|l|c|c|c|c|c|c|c|c|}
\hline \multicolumn{7}{|c|}{ Table 2: At what age did you start your doctoral program? } \\
\hline & \multicolumn{7}{|c|}{ Israel } & \multicolumn{3}{c|}{ Western Europe } \\
\hline & Total & $\begin{array}{c}\text { Social } \\
\text { Sciences }\end{array}$ & Humanities & Sci. & Eng. & Sci. & Eng. & Total \\
\cline { 2 - 9 } & $\mathrm{n}=1013$ & $\mathrm{n}=153$ & $\mathrm{n}=153$ & $\mathrm{n}=344$ & $\mathrm{n}=122$ & $\mathrm{n}=103$ & $\mathrm{n}=257$ & $\mathrm{n}=457$ \\
\hline under 25 & $3.2 \%$ & $1.3 \%$ & $2.6 \%$ & $5.8 \%$ & $0.8 \%$ & $39.8 \%$ & $15.6 \%$ & $22.6 \%$ \\
\hline $25-29$ & $31.6 \%$ & $20.9 \%$ & $17.6 \%$ & $48.8 \%$ & $44.3 \%$ & $41.7 \%$ & $51.4 \%$ & $48.4 \%$ \\
\hline $30-34$ & $30.8 \%$ & $32.7 \%$ & $34.6 \%$ & $32.6 \%$ & $29.5 \%$ & $7.8 \%$ & $7.0 \%$ & $7.9 \%$ \\
\hline $35-39$ & $13.3 \%$ & $22.2 \%$ & $15.0 \%$ & $6.4 \%$ & $12.3 \%$ & $0.0 \%$ & $3.9 \%$ & $2.7 \%$ \\
\hline over 40 & $18.1 \%$ & $22.2 \%$ & $29.4 \%$ & $3.2 \%$ & $8.2 \%$ & $0.0 \%$ & $1.9 \%$ & $1.7 \%$ \\
\hline $\begin{array}{l}\text { Not Speci- } \\
\text { fied }\end{array}$ & $3.1 \%$ & $0.7 \%$ & $0.7 \%$ & $3.2 \%$ & $4.9 \%$ & $10.7 \%$ & $20.2 \%$ & $16.7 \%$ \\
\hline
\end{tabular}

\section{Q3: Why did you decide to study towards a PhD?}

Over $50 \%$ of all candidates studied towards a $\mathrm{PhD}$ because they were interested in attaining higher education. It is interesting to note that about $10 \%$ of all students decided to study towards the 
$\mathrm{PhD}$ as a default choice. In this study, we were interested in learning how many candidates were enrolled in the doctoral program because they were interested in an academic career (Table 3).

In Israel, $19.27 \%$ of S\&E students planned to become professors, while in SS\&H, 35.00\% wanted to become professors. This presented a significant difference in the answer pattern $(\mathrm{DF}=1$, $\left.\chi^{2}=23.16, \mathrm{p}<.0001\right)$.

In Israel, $19.27 \%$ of S\&E students planned to become professors after graduating with only $16.48 \%$ in Western Europe. In this case, there was no significant difference between the patterns $\left(\mathrm{DF}=1, \chi^{2}=1.04, \mathrm{p}=0.31\right)$.

\begin{tabular}{|l|c|c|c|c|c|c|c|c|}
\hline \multicolumn{7}{|c|}{ Table 3: Why did you decide to study towards a PhD? } \\
\hline & Total & $\begin{array}{c}\text { Social } \\
\text { Sciences }\end{array}$ & $\begin{array}{c}\text { Humanitie } \\
\text { s }\end{array}$ & Sci. & Eng. & Sci. & Eng. & Total \\
\cline { 2 - 9 } & $\begin{array}{c}\mathrm{n}=101 \\
3\end{array}$ & $\mathrm{n}=153$ & $\mathrm{n}=153$ & $\begin{array}{c}\mathrm{n}=34 \\
4\end{array}$ & $\begin{array}{c}\mathrm{n}=12 \\
2\end{array}$ & $\begin{array}{c}\mathrm{n}=10 \\
3\end{array}$ & $\mathrm{n}=257$ & $\begin{array}{c}\mathrm{n}=45 \\
7\end{array}$ \\
\hline $\begin{array}{l}\text { I am interested in be- } \\
\text { coming a professor }\end{array}$ & $27.4 \%$ & $37.3 \%$ & $31.4 \%$ & $\begin{array}{c}24.7 \\
\%\end{array}$ & $\begin{array}{c}16.4 \\
\%\end{array}$ & $\begin{array}{c}12.6 \\
\%\end{array}$ & $17.9 \%$ & $\begin{array}{c}17.4 \\
\%\end{array}$ \\
\hline $\begin{array}{l}\text { I am interested in attain- } \\
\text { ing higher education }\end{array}$ & $50.5 \%$ & $40.5 \%$ & $49.7 \%$ & $\begin{array}{c}47.1 \\
\%\end{array}$ & $\begin{array}{c}68.0 \\
\%\end{array}$ & $\begin{array}{c}71.8 \\
\%\end{array}$ & $65.8 \%$ & $\begin{array}{c}65.1 \\
\%\end{array}$ \\
\hline $\begin{array}{l}\text { It is likely to help me } \\
\text { attain a higher income }\end{array}$ & $10.2 \%$ & $11.1 \%$ & $3.9 \%$ & $\begin{array}{c}13.7 \\
\%\end{array}$ & $6.6 \%$ & $5.8 \%$ & $9.3 \%$ & $8.6 \%$ \\
\hline It was a default choice & $10.5 \%$ & $9.2 \%$ & $13.1 \%$ & $\begin{array}{c}13.1 \\
\%\end{array}$ & $9.0 \%$ & $9.7 \%$ & $6.2 \%$ & $8.1 \%$ \\
\hline Not Specified & $1.4 \%$ & $2.0 \%$ & $2.0 \%$ & $1.5 \%$ & $0.0 \%$ & $0.0 \%$ & $0.8 \%$ & $0.7 \%$ \\
\hline
\end{tabular}

\section{Q4: How many hours per week do you devote to your doctoral research?}

More than 55\% of SS\&H students spent fewer than 30 hours per week on their research, while over $55 \%$ of S\&E students, in Israel and Western Europe, spent more than 45 hours per week on their research (Table 4).

\begin{tabular}{|l|c|c|c|c|c|c|c|c|}
\hline \multicolumn{7}{|c|}{ Table 4: How much time per week do you devote to your doctoral research? } \\
\hline & Total & $\begin{array}{c}\text { Social } \\
\text { Scienc- } \\
\text { es }\end{array}$ & $\begin{array}{c}\text { Humanitie } \\
\text { s }\end{array}$ & Sci. & Eng. & Sci. & Eng. & Total \\
\cline { 2 - 10 } & $\mathrm{n}=1013$ & $\mathrm{n}=153$ & $\mathrm{n}=153$ & $\mathrm{n}=344$ & $\mathrm{n}=122$ & $\mathrm{n}=103$ & $\mathrm{n}=257$ & $\mathrm{n}=457$ \\
\hline All my time, 24/7 & $6.1 \%$ & $5.2 \%$ & $1.3 \%$ & $9.0 \%$ & $8.2 \%$ & $3.9 \%$ & $8.6 \%$ & $7.4 \%$ \\
\hline $\begin{array}{l}\text { Over } 60 \text { hours per } \\
\text { week }\end{array}$ & $8.8 \%$ & $3.9 \%$ & $5.2 \%$ & $13.1 \%$ & $14.8 \%$ & $15.5 \%$ & $\begin{array}{c}10.1 \\
\%\end{array}$ & $\begin{array}{c}10.8 \\
\%\end{array}$ \\
\hline $\begin{array}{l}45-60 \text { hours per } \\
\text { week }\end{array}$ & $25.7 \%$ & $8.5 \%$ & $15.7 \%$ & $39.8 \%$ & $31.1 \%$ & $54.4 \%$ & $\begin{array}{c}36.6 \\
\%\end{array}$ & $\begin{array}{c}39.8 \\
\%\end{array}$ \\
\hline $\begin{array}{l}30-45 \text { hours per } \\
\text { week }\end{array}$ & $25.6 \%$ & $24.2 \%$ & $24.8 \%$ & $29.9 \%$ & $21.3 \%$ & $23.3 \%$ & $\begin{array}{c}30.4 \\
\%\end{array}$ & $\begin{array}{c}30.2 \\
\%\end{array}$ \\
\hline $\begin{array}{l}15-30 \text { hours per } \\
\text { week }\end{array}$ & $18.4 \%$ & $28.1 \%$ & $27.5 \%$ & $6.1 \%$ & $18.9 \%$ & $1.9 \%$ & $9.3 \%$ & $7.6 \%$ \\
\hline $\begin{array}{l}0-15 \text { hours per } \\
\text { week }\end{array}$ & $15.3 \%$ & $30.1 \%$ & $24.8 \%$ & $2.0 \%$ & $5.7 \%$ & $1.0 \%$ & $5.1 \%$ & $4.2 \%$ \\
\hline Not Specified & $0.2 \%$ & $0.0 \%$ & $0.7 \%$ & $0.0 \%$ & $0.0 \%$ & $0.0 \%$ & $0.0 \%$ & $0.0 \%$ \\
\hline
\end{tabular}

In Israel, students in S\&E devoted much more time for doctoral research than their colleagues in $\mathrm{SS} \& \mathrm{H}-\mathrm{a}$ significant difference in the pattern of their answers $\left(\mathrm{DF}=5, \chi^{2}=191.93, \mathrm{p}<.0001\right)$ 
When we compared the time devoted to doctoral research by S\&E students in Israeli universities and their counterparts in Western European universities, we found no significant difference $\left(\mathrm{DF}=5, \chi^{2}=3.72, \mathrm{p}<.59\right)$.

\section{Summary}

Based on the answers received from Israeli candidates, we could clearly state that there were different patterns from among S\&E students and their peers in SS\&H. The S\&E candidates started their doctoral program at a younger age than their colleagues in SS\&H. Significantly, more S\&E students were enrolled as full-time students. The S\&E candidates devoted more time per week to research as compared to their colleagues in SS\&H. The interest of S\&E candidates in becoming professors in academia was significantly lower than that of their colleagues in SS\&H.

We also compared the patterns of S\&E students in Israel and Western Europe. In both places, about $92 \%$ percent of the candidates were enrolled as full-time students. The students in Western Europe started their doctoral programs at a significantly younger age. We found there was no significant difference between the percentages of S\&E students in Israel and Western Europe who planned to become professors. In both places, only less than $20 \%$ of the candidates planned to remain in academia. When we statistically analyzed the pattern of weekly hours devoted by S\&E students to doctoral research, we found that the that there was no significant difference between Israel and Western Europe.

\section{Managerial Skills}

\section{Q5: Have you had any managerial experience prior to your PhD studies? If so, has it been helpful?}

More than $50 \%$ of all students answered that they had no prior managerial experience (Table 5). In general, Israeli students started their programs at an older age and after several years of work. Therefore, they may have had more managerial experience.

We decided to compare the answer "yes, it helps", with all other answers practically indicating that the student did not apply managerial skills in his or her research.

In Israel, $20.61 \%$ of S\&E students used managerial skills that helped them, while in SS\&H, $30.1 \%$ used managerial skills. This presented a significant difference in the answer pattern $\left(\mathrm{DF}=1, \chi^{2}=8.875, \mathrm{p}=.0029\right)$.

In Israel, $20.61 \%$ of S\&E students applied helpful managerial experience while in Western Europe $23.68 \%$ used managerial skills. No significant difference was found in their answer pattern $\left(\mathrm{DF}=1, \chi^{2}=1.101, \mathrm{p}=.291\right)$.

\begin{tabular}{|c|c|c|c|c|c|c|c|c|}
\hline \multicolumn{9}{|c|}{$\begin{array}{l}\text { Table 5: Have you had any managerial experience prior to the PhD studies? } \\
\text { If so, has it been helpful? }\end{array}$} \\
\hline & \multicolumn{5}{|c|}{ Israel } & \multicolumn{3}{|c|}{ Western Europe } \\
\hline & Total & $\begin{array}{c}\text { Social } \\
\text { Sciences }\end{array}$ & $\begin{array}{c}\text { Humanitie } \\
\text { s }\end{array}$ & Sci. & Eng. & Sci. & Eng. & Total \\
\hline & $\begin{array}{c}\mathrm{n}=101 \\
3\end{array}$ & $\mathrm{n}=153$ & $\mathrm{n}=153$ & $\begin{array}{c}n=34 \\
4\end{array}$ & $\begin{array}{c}n=12 \\
2\end{array}$ & $\begin{array}{c}\mathrm{n}=10 \\
3\end{array}$ & $\begin{array}{c}\mathrm{n}=25 \\
7\end{array}$ & $\begin{array}{c}\mathrm{n}=45 \\
7\end{array}$ \\
\hline $\begin{array}{l}\text { Yes, but it is not relevant } \\
\text { and does not help }\end{array}$ & $17.9 \%$ & $20.3 \%$ & $29.4 \%$ & $\begin{array}{c}13.4 \\
\%\end{array}$ & $\begin{array}{c}20.5 \\
\%\end{array}$ & $6.8 \%$ & $9.7 \%$ & $8.6 \%$ \\
\hline Yes, it helps & $27.6 \%$ & $35.9 \%$ & $22.9 \%$ & $\begin{array}{c}17.4 \\
\%\end{array}$ & $\begin{array}{c}28.7 \\
\%\end{array}$ & $\begin{array}{c}14.6 \\
\%\end{array}$ & $\begin{array}{c}27.2 \\
\%\end{array}$ & $\begin{array}{c}25.1 \\
\%\end{array}$ \\
\hline $\begin{array}{l}\text { No prior managerial ex- } \\
\text { perience }\end{array}$ & $53.0 \%$ & $41.2 \%$ & $45.8 \%$ & $\begin{array}{c}68.0 \\
\%\end{array}$ & $\begin{array}{c}50.0 \\
\%\end{array}$ & $\begin{array}{c}78.6 \\
\%\end{array}$ & $\begin{array}{c}62.6 \\
\%\end{array}$ & $\begin{array}{c}66.1 \\
\%\end{array}$ \\
\hline Not Specified & $1.5 \%$ & $2.6 \%$ & $2.0 \%$ & $1.2 \%$ & $0.8 \%$ & $0.0 \%$ & $0.4 \%$ & $0.2 \%$ \\
\hline
\end{tabular}




\section{Q6: Is doctoral research a project?}

The majority of all candidates replied that doctoral research is a project (Table 6). Considerably more SS\&H students answered correctly. We compared the positive answer "yes, it is a project" with the other two answers that indicated that the student did not know whether doctoral research is a project.

In Israel, $54 \%$ of S\&E students answered that doctoral research is a project compared to $71.76 \%$ of SS\&H students. We observed a significant difference $\left(\mathrm{DF}=1, \chi^{2}=24.190, \mathrm{p}<.0001\right)$.

In Western Europe, $59.5 \%$ of S\&E students answered that it is a project, compared to $54 \%$ in Israel, presenting a non-significant difference in the answer pattern $\left(\mathrm{DF}=1, \chi^{2}=2.480, \mathrm{p}=0.115\right)$.

\begin{tabular}{|l|c|c|c|c|c|c|c|c|}
\hline \multicolumn{7}{|c|}{ Table 6: Is doctoral research a project? } \\
\hline & \multicolumn{3}{|c|}{ Israel } & \multicolumn{3}{c|}{ Western Europe } \\
\hline & Total & $\begin{array}{c}\text { Social } \\
\text { Sciences }\end{array}$ & Humanities & Sci. & Eng. & Sci. & Eng. & Total \\
\cline { 2 - 10 } & $\mathrm{n}=1013$ & $\mathrm{n}=153$ & $\mathrm{n}=153$ & $\mathrm{n}=344$ & $\mathrm{n}=122$ & $\mathrm{n}=103$ & $\mathrm{n}=257$ & $\mathrm{n}=457$ \\
\hline Yes, it is a project & $64.4 \%$ & $75.2 \%$ & $66.0 \%$ & $52.3 \%$ & $57.4 \%$ & $61.2 \%$ & $58.4 \%$ & $58.7 \%$ \\
\hline No, it is not a project & $8.4 \%$ & $5.9 \%$ & $5.2 \%$ & $10.2 \%$ & $14.8 \%$ & $11.7 \%$ & $16.7 \%$ & $16.0 \%$ \\
\hline $\begin{array}{l}\text { Maybe, but I do not } \\
\text { know }\end{array}$ & $26.2 \%$ & $18.3 \%$ & $26.1 \%$ & $36.9 \%$ & $27.0 \%$ & $26.2 \%$ & $24.5 \%$ & $24.8 \%$ \\
\hline Not Specified & $1.1 \%$ & $0.7 \%$ & $2.6 \%$ & $0.6 \%$ & $0.8 \%$ & $1.0 \%$ & $0.4 \%$ & $0.5 \%$ \\
\hline
\end{tabular}

Q7: Have you learned how to manage your PhD tasks? (How to manage your time, how to plan and execute tasks...)

Fewer than $5 \%$ of all candidates learned how to manage doctoral research, and about the same percentage thought that there was no need to manage PhD tasks (Table 7).

\begin{tabular}{|l|c|c|c|c|c|c|c|c|}
\hline \multicolumn{7}{|c|}{ Table 7: Have you learned how to manage your PhD tasks? } \\
(How to manage your time, how to plan and execute tasks...) \\
\hline & Total & $\begin{array}{c}\text { Social } \\
\text { Sciences }\end{array}$ & Humanities & Sci. & Eng. & Sci. & Eng. & Total \\
\cline { 2 - 10 } & $\mathrm{n}=1013$ & $\mathrm{n}=153$ & $\mathrm{n}=153$ & $\mathrm{n}=344$ & $\mathrm{n}=122$ & $\mathrm{n}=103$ & $\mathrm{n}=257$ & $\mathrm{n}=457$ \\
\hline $\begin{array}{l}\text { There is no need to man- } \\
\text { age PhD tasks }\end{array}$ & $4.5 \%$ & $5.2 \%$ & $5.2 \%$ & $4.9 \%$ & $4.9 \%$ & $7.8 \%$ & $5.4 \%$ & $6.1 \%$ \\
\hline $\begin{array}{l}\text { I have not learned how to } \\
\text { manage PhD tasks }\end{array}$ & $52.2 \%$ & $54.2 \%$ & $63.4 \%$ & $46.5 \%$ & $57.4 \%$ & $51.5 \%$ & $40.5 \%$ & $45.2 \%$ \\
\hline $\begin{array}{l}\text { I go through "on-the-job } \\
\text { training" }\end{array}$ & $37.6 \%$ & $33.3 \%$ & $23.5 \%$ & $44.8 \%$ & $32.8 \%$ & $39.8 \%$ & $49.0 \%$ & $44.0 \%$ \\
\hline $\begin{array}{l}\text { I attended a seminar or a } \\
\text { class }\end{array}$ & $4.0 \%$ & $6.5 \%$ & $5.9 \%$ & $2.0 \%$ & $3.3 \%$ & $1.0 \%$ & $5.1 \%$ & $4.7 \%$ \\
\hline Not Specified & $1.6 \%$ & $0.7 \%$ & $2.0 \%$ & $1.7 \%$ & $1.6 \%$ & $0.0 \%$ & $0.0 \%$ & $0.0 \%$ \\
\hline
\end{tabular}

Only $6.29 \%$ of SS\&H students in Israel attended a seminar or studied how to manage their doctoral research, and only $2.4 \%$ of S\&E students attended such training. Although statistically there is a significant difference between the two academic fields $(\mathrm{DF}=3$, Chi-Square $=19.011$, $\mathrm{p}=0.0003$ ), practically, the vast majority of all students have not learned how to manage doctoral research tasks. 
Only $3.89 \%$ of S\&E students in Western Europe attended such a class, so the answer patterns in Israel and Western Europe showed no significant difference $\left(\mathrm{DF}=3, \chi^{2}=4.495, \mathrm{p}=0.213\right)$.

\section{Q8: Do you have an up-to-date plan for your research thesis?}

About one quarter of all candidates in Israel and Western Europe, in all academic fields, replied that they had a written an updated plan that they used (Table 8).

In Israel, the answers from S\&E candidates and from SS\&H students presented a similar pattern showing no significant difference $\left(\mathrm{DF}=3, \chi^{2}=0.955, \mathrm{p}=0.812\right)$.

Also, when comparing the answers of S\&E students in Israel and in Western Europe, we obtained answer patterns without significant differences $\left(\mathrm{DF}=3, \chi^{2}=0.505, \mathrm{p}=0.918\right)$.

\begin{tabular}{|l|c|c|c|c|c|c|c|c|}
\hline \multicolumn{7}{|c|}{ Table 8: Do you have an up-to-date plan for your research thesis? } \\
\hline & \multicolumn{7}{|c|}{ Israel } & \multicolumn{3}{c|}{ Western Europe } \\
\hline & Total & $\begin{array}{c}\text { Social } \\
\text { Sciences }\end{array}$ & Humanities & Sci. & Eng. & Sci. & Eng. & Total \\
\cline { 2 - 10 } & $\mathrm{n}=1013$ & $\mathrm{n}=153$ & $\mathrm{n}=153$ & $\mathrm{n}=344$ & $\mathrm{n}=122$ & $\mathrm{n}=103$ & $\mathrm{n}=257$ & $\mathrm{n}=457$ \\
\hline $\begin{array}{l}\text { There is no need for } \\
\text { such a plan }\end{array}$ & $3.2 \%$ & $3.3 \%$ & $3.3 \%$ & $3.5 \%$ & $4.9 \%$ & $2.9 \%$ & $3.5 \%$ & $3.4 \%$ \\
\hline I do not have a plan & $24.5 \%$ & $25.5 \%$ & $24.8 \%$ & $28.2 \%$ & $23.8 \%$ & $33.0 \%$ & $24.9 \%$ & $27.0 \%$ \\
\hline $\begin{array}{l}\text { I have a plan, but it } \\
\text { is not up to date }\end{array}$ & $40.0 \%$ & $42.5 \%$ & $38.6 \%$ & $41.6 \%$ & $43.4 \%$ & $35.0 \%$ & $48.2 \%$ & $44.2 \%$ \\
\hline $\begin{array}{l}\text { I have a written and } \\
\text { updated plan }\end{array}$ & $30.5 \%$ & $25.5 \%$ & $30.7 \%$ & $25.0 \%$ & $27.0 \%$ & $28.2 \%$ & $23.0 \%$ & $24.8 \%$ \\
\hline Not Specified & $1.9 \%$ & $3.3 \%$ & $2.6 \%$ & $1.7 \%$ & $0.8 \%$ & $1.0 \%$ & $0.4 \%$ & $0.5 \%$ \\
\hline
\end{tabular}

\section{Q9: While working on your $\mathrm{PhD}$ thesis who is your "customer"?}

The majority of all candidates replied that their peers in the academic community were their customers (Table 9).

First, we analyzed the pattern of all six multiple choice answers and made a comparison between the academic disciplines.

In Israel, the pattern of the responses from S\&E students and from SS\&H students showed no significant difference $\left(\mathrm{DF}=5, \chi^{2}=6.392, \mathrm{p}=0.270\right)$.

Comparing the answers from Israeli and Western European S\&E students, there was a significant difference in the answer pattern $\left(\mathrm{DF}=5, \chi^{2}=24.235, \mathrm{p}=0.0002\right)$.

Next, we selected the answer, "My adviser," which was the correct answer to this question, and compared it with the aggregate of all other answers.

In Israel, $25.60 \%$ of S\&E students gave this answer, as compared to $22.38 \%$ of SS\&H students. This presented a similar pattern with no significant difference $\left(\mathrm{DF}=1, \chi^{2}=0.992, \mathrm{p}=0.319\right)$.

In Western Europe, $21.13 \%$ of S\&E students selected the adviser as the correct answer presenting no significant difference relative to Israeli $S \& E$ students $\left(D F=1, \chi^{2}=2.216, p=0.136\right)$. 


\begin{tabular}{|l|c|c|c|c|c|c|c|c|}
\hline \multicolumn{7}{|c|}{ Table 9: While working on your PhD thesis who is your "customer"? } \\
\hline & \multicolumn{3}{|c|}{ Israel } & \multicolumn{3}{c|}{ Western Europe } \\
\hline & Total & $\begin{array}{c}\text { Social } \\
\text { Sciences }\end{array}$ & Humanities & Sci. & Eng. & Sci. & Eng. & Total \\
\cline { 2 - 10 } & $\mathrm{n}=1013$ & $\mathrm{n}=153$ & $\mathrm{n}=153$ & $\mathrm{n}=344$ & $\mathrm{n}=122$ & $\mathrm{n}=103$ & $\mathrm{n}=257$ & $\mathrm{n}=457$ \\
\hline $\begin{array}{l}\text { My peers in the scien- } \\
\text { tific community }\end{array}$ & $39.9 \%$ & $41.8 \%$ & $43.8 \%$ & $43.6 \%$ & $32.8 \%$ & $43.7 \%$ & $53.7 \%$ & $48.9 \%$ \\
\hline My adviser & $24.2 \%$ & $17.6 \%$ & $24.2 \%$ & $23.3 \%$ & $30.3 \%$ & $21.4 \%$ & $20.6 \%$ & $21.4 \%$ \\
\hline The department & $2.2 \%$ & $2.6 \%$ & $2.6 \%$ & $1.7 \%$ & $0.0 \%$ & $4.9 \%$ & $3.5 \%$ & $3.9 \%$ \\
\hline The university & $3.4 \%$ & $1.3 \%$ & $5.2 \%$ & $1.5 \%$ & $4.9 \%$ & $5.8 \%$ & $3.9 \%$ & $4.9 \%$ \\
\hline My family & $0.9 \%$ & $0.0 \%$ & $2.0 \%$ & $0.6 \%$ & $0.0 \%$ & $1.9 \%$ & $0.4 \%$ & $0.7 \%$ \\
\hline Myself & $25.8 \%$ & $29.4 \%$ & $16.3 \%$ & $27.0 \%$ & $31.1 \%$ & $19.4 \%$ & $17.1 \%$ & $18.4 \%$ \\
\hline Not Specified & $3.8 \%$ & $7.2 \%$ & $5.9 \%$ & $2.3 \%$ & $0.8 \%$ & $2.9 \%$ & $0.8 \%$ & $1.7 \%$ \\
\hline
\end{tabular}

\section{Summary}

Based on these results, it was quite clear that, although the majority of candidates (more than $55 \%$ ) understood that a doctoral research is a project, more than $95 \%$ of the students have not learned how to manage a research project, and in practice they worked without planning their work consistently. Only about one quarter of the students answered that they worked using an updated plan, which meant that all the rest worked without one. About three quarters of doctoral candidates in all disciplines and locations lacked the management skills needed to efficiently complete a doctoral thesis.

The answer to the question "who is your customer while working on a doctoral research," is central for understanding adviser-candidate relations and the formation of potential conflicts and crises. Based on candidates' replies, it was obvious that most candidates, regardless of their academic field or university location, did not understand the difference between the project's customer and the project's stakeholders or users. The majority of candidates replied that their customers are their peers in the academic world.

\section{Relations with the Adviser}

\section{Q10: How frequently do you meet with your adviser?}

Looking at Table 10, we can see that SS\&H students met their advisers much less than their colleagues in S\&E. First, we compared all five multi-choice answers among themselves to find a pattern. Next, we examined the two answers to the question: How many met the adviser once a week or how many met their adviser once a semester?

In Israel there was a significant difference in the general pattern of meeting with the adviser between $\mathrm{S} \& E$ students an SS\&H students $\left(\mathrm{DF}=4, \chi^{2}=311.490, \mathrm{p}<.0001\right)$. Additionally, when comparing the answers from $S \& E$ students in Israel and to those from Western Europe, there was a significant difference in the answer pattern $\left(\mathrm{DF}=4, \chi^{2}=44.955, \mathrm{p}<.0001\right)$.

In Israel, $63.91 \%$ of S\&E students met their adviser once a week while only $11.59 \%$ of SS\&H students meet weekly, providing a significant difference in the pattern $\left(\mathrm{DF}=1, \chi^{2}=203.438\right.$, $\mathrm{p}<.0001$ ). However, $33.77 \%$ of SS\&H students met with the adviser once a semester while only $2.37 \%$ of $\mathrm{S} \& \mathrm{E}$ students met once a semester. $\left(\mathrm{DF}=1, \chi^{2}=156.043, \mathrm{p}<.0001\right)$.

In Western Europe, $43.89 \%$ of S\&E students met with their adviser weekly - about $20 \%$ less than $\mathrm{S} \& \mathrm{E}$ students in Israel - presenting a significantly different pattern $\left(\mathrm{DF}=1, \chi^{2}=32.734, \mathrm{p}<.0001\right)$. In Israel, only $2.83 \%$ of $\mathrm{S} \& \mathrm{E}$ students met with their adviser once a semester while in Western Europe $7.78 \%$ did, also a significantly different pattern $\left(\mathrm{DF}=1, \chi^{2}=10.425, \mathrm{p}<.0012\right)$. 


\begin{tabular}{|l|c|c|c|c|c|c|c|c|}
\hline \multicolumn{7}{|c|}{ Table 10: How frequently do you meet your adviser? } \\
\hline & \multicolumn{7}{|c|}{ Israel } & \multicolumn{3}{c|}{ Western Europe } \\
\hline & Total & $\begin{array}{c}\text { Social } \\
\text { Sciences }\end{array}$ & Humanities & Sci. & Eng. & Sci. & Eng. & Total \\
\cline { 2 - 10 } & $\mathrm{n}=1013$ & $\mathrm{n}=153$ & $\mathrm{n}=153$ & $\mathrm{n}=344$ & $\mathrm{n}=122$ & $\mathrm{n}=103$ & $\mathrm{n}=257$ & $\mathrm{n}=457$ \\
\hline Once a week & $37.7 \%$ & $14.4 \%$ & $8.5 \%$ & $64.5 \%$ & $59.0 \%$ & $48.5 \%$ & $42.0 \%$ & $41.0 \%$ \\
\hline $\begin{array}{l}\text { Once every oth- } \\
\text { er week }\end{array}$ & $18.8 \%$ & $17.6 \%$ & $11.1 \%$ & $21.2 \%$ & $25.4 \%$ & $23.3 \%$ & $26.8 \%$ & $25.3 \%$ \\
\hline Monthly & $23.9 \%$ & $35.9 \%$ & $36.6 \%$ & $10.5 \%$ & $10.7 \%$ & $17.5 \%$ & $24.5 \%$ & $24.8 \%$ \\
\hline Once a semester & $16.8 \%$ & $28.8 \%$ & $37.9 \%$ & $1.7 \%$ & $4.1 \%$ & $10.7 \%$ & $6.2 \%$ & $8.6 \%$ \\
\hline Once a year & $1.6 \%$ & $2.6 \%$ & $3.9 \%$ & $0.6 \%$ & $0.0 \%$ & $0.0 \%$ & $0.4 \%$ & $0.2 \%$ \\
\hline Not Specified & $1.3 \%$ & $0.7 \%$ & $2.0 \%$ & $1.5 \%$ & $0.8 \%$ & $0.0 \%$ & $0.0 \%$ & $0.0 \%$ \\
\hline
\end{tabular}

\section{Q11: Do you think that your adviser has managerial skills?}

More than one third of all students answered that their adviser was a good manager and helped them to plan their research (Table 11).

In Israel, $37.69 \%$ of the S\&E students answered that their adviser was a good manager and $40.07 \%$ of SS\&H students gave a similar answer. The pattern of the answers to this question showed no significant difference between both academic disciplines in Israel $\left(\mathrm{DF}=2, \chi^{2}=0.427\right.$, $\mathrm{p}=0.807)$.

In Israel, $37.69 \%$ of S\&E students answered that their adviser was a good manager, while $40.07 \%$ of S\&E students Western Europe gave a similar answer. The answer pattern to this question showed that there is no significant difference between Western Europe and Israel $(\mathrm{DF}=2$, $\left.\chi^{2}=1.388, \mathrm{p}=0.497\right)$.

\begin{tabular}{|c|c|c|c|c|c|c|c|c|}
\hline \multicolumn{9}{|c|}{ Table 11: Do you think that your adviser has managerial skills? } \\
\hline & \multicolumn{5}{|c|}{ Israel } & \multicolumn{3}{|c|}{ Western Europe } \\
\hline & Total & $\begin{array}{c}\text { Social } \\
\text { Sciences }\end{array}$ & $\begin{array}{c}\text { Humanitie } \\
s\end{array}$ & Sci. & Eng. & Sci. & Eng. & Total \\
\hline & $\begin{array}{c}\mathrm{n}=101 \\
3\end{array}$ & $\mathrm{n}=153$ & $\mathrm{n}=153$ & $\begin{array}{c}\mathrm{n}=34 \\
4\end{array}$ & $\begin{array}{c}\mathrm{n}=12 \\
2\end{array}$ & $\begin{array}{c}\mathrm{n}=10 \\
3\end{array}$ & $\begin{array}{c}n=25 \\
7\end{array}$ & $\mathrm{n}=457$ \\
\hline $\begin{array}{l}\text { My adviser is a scientist, } \\
\text { has no managerial skills }\end{array}$ & $18.8 \%$ & $19.6 \%$ & $17.0 \%$ & $\begin{array}{c}21.2 \\
\%\end{array}$ & $\begin{array}{c}14.8 \\
\%\end{array}$ & $\begin{array}{c}24.3 \\
\%\end{array}$ & $\begin{array}{c}20.6 \\
\%\end{array}$ & $21.9 \%$ \\
\hline $\begin{array}{l}\text { My adviser has manageri- } \\
\text { al skills but is interested } \\
\text { only in science }\end{array}$ & $39.1 \%$ & $36.6 \%$ & $41.2 \%$ & $\begin{array}{c}43.0 \\
\%\end{array}$ & $\begin{array}{c}38.5 \\
\%\end{array}$ & $\begin{array}{c}42.7 \\
\%\end{array}$ & $\begin{array}{c}36.2 \\
\%\end{array}$ & $37.3 \%$ \\
\hline $\begin{array}{l}\text { My adviser is a good } \\
\text { manager, shows me how } \\
\text { to plan }\end{array}$ & $39.3 \%$ & $41.2 \%$ & $35.3 \%$ & $\begin{array}{c}34.3 \\
\%\end{array}$ & $\begin{array}{c}45.1 \\
\%\end{array}$ & $\begin{array}{c}33.0 \\
\%\end{array}$ & $\begin{array}{c}41.6 \\
\%\end{array}$ & $39.8 \%$ \\
\hline Not Specified & $2.9 \%$ & $2.6 \%$ & $6.5 \%$ & $1.5 \%$ & $1.6 \%$ & $0.0 \%$ & $1.6 \%$ & $1.0 \%$ \\
\hline
\end{tabular}

\section{Q12: What is your adviser's contribution to your research thesis' advancement?}

More than $40 \%$ of the total population of students answered that their adviser had a major contribution in advising and directing, with over $30 \%$ being in scientific advice (Table 12).

In this question, we were interested in statistically analyzing two extreme answers: "My adviser has a major contribution in advising and directing" and "No substantial contribution." 
In Israel, $51.40 \%$ of S\&E students answered that the adviser made a major contribution to their research and 46.15 of the SS\&H students provided the same answer. There was no significant difference in the pattern $\left(\mathrm{DF}=1, \chi^{2}=2.003, \mathrm{p}=0.157\right)$.

Only $2.38 \%$ of S\&E candidates answered that the adviser made no contribution as did $6.69 \%$ of SS\&H students, presenting a significant difference in the answer pattern $\left(\mathrm{DF}=1, \chi^{2}=8.660\right.$, $\mathrm{p}=0.003)$.

Some $51.40 \%$ of Israeli S\&E students answered that the adviser made a major contribution to their research while only $40.22 \%$ of students in Western Europe answered the same way. (DF=1, $\left.\chi^{2}=10.144, p=0.001\right)$.

Compared to the $2.38 \%$ of $\mathrm{S} \& \mathrm{E}$ candidates in Israel who answered that the adviser made no contribution; in Western Europe, $10.06 \%$ of the candidates gave that answer $\left(\mathrm{DF}=1, \chi^{2}=22.065\right.$, $\mathrm{p}<.0001)$.

Table 12: What is the contribution of your adviser to your research thesis advancement?

\begin{tabular}{|l|c|c|c|c|c|c|c|c|}
\hline & \multicolumn{5}{|c|}{ Israel } & \multicolumn{3}{|c|}{ Western Europe } \\
\hline & $\mathrm{n}=1013$ & $\mathrm{n}=153$ & $\mathrm{n}=153$ & $\mathrm{n}=344$ & $\mathrm{n}=122$ & $\mathrm{n}=103$ & $\mathrm{n}=257$ & $\mathrm{n}=457$ \\
\hline $\begin{array}{l}\text { Sciences } \\
\text { advising contribution in }\end{array}$ & Humanities & Sci. & Eng. & Sci. & Eng. & Total \\
\hline $\begin{array}{l}\text { Major contribution in } \\
\text { scientific advising }\end{array}$ & $49.6 \%$ & $40.5 \%$ & $49.7 \%$ & $50.3 \%$ & $53.3 \%$ & $36.9 \%$ & $41.2 \%$ & $40.0 \%$ \\
\hline $\begin{array}{l}\text { Minor contribution in } \\
\text { supporting and en- } \\
\text { couraging }\end{array}$ & $14.9 \%$ & $18.3 \%$ & $17.0 \%$ & $13.4 \%$ & $20.5 \%$ & $17.5 \%$ & $19.5 \%$ & $18.9 \%$ \\
\hline $\begin{array}{l}\text { No substantial contri- } \\
\text { bution }\end{array}$ & $4.1 \%$ & $5.9 \%$ & $7.2 \%$ & $2.3 \%$ & $2.5 \%$ & $10.7 \%$ & $9.7 \%$ & $10.1 \%$ \\
\hline Not Specified & $1.4 \%$ & $2.0 \%$ & $2.6 \%$ & $0.6 \%$ & $0.8 \%$ & $0.0 \%$ & $0.8 \%$ & $0.5 \%$ \\
\hline
\end{tabular}

Q13: Have there been disagreements with your adviser? What was the background for these disagreements?

More than $50 \%$ of the total population of all students answered that they had no disagreement with the adviser (Table 13). In Israel, 58.8\% of SS\&H students reported that they had no disagreements with their adviser, while $50.55 \%$ of S\&E students had no disagreements. The most prevalent disagreement is "Professional disagreement," where the adviser and the student have different approaches or opinions about the research. Some $19.27 \%$ of SS\&H students reported that they encountered professional disagreement while $22.98 \%$ of Israeli S\&E students disagreed on a professional basis. The patterns of the answers showed no significant difference ( $D F=4, \chi^{2}=6.443$, $\mathrm{p}=0.168)$.

About $64.15 \%$ of S\&E Western European candidates had no disagreements with their adviser, compared to Israel with only $50.55 \%$. Only $11.48 \%$ of Western European students reported professional disagreements, compared to $22.98 \%$ in Israel. When comparing answers from S\&E students in Israel and Western Europe, the answer pattern showed a significant difference $(\mathrm{DF}=4$, Chi-Square $=\chi^{2}, \mathrm{p}=0.0002$ ). 


\begin{tabular}{|c|c|c|c|c|c|c|c|c|}
\hline \multicolumn{9}{|c|}{$\begin{array}{l}\text { Table 13: Have there been disagreements with your adviser? } \\
\text { What was the background for these disagreements? }\end{array}$} \\
\hline & \multicolumn{5}{|c|}{ Israel } & \multicolumn{3}{|c|}{ Western Europe } \\
\hline & Total & $\begin{array}{c}\text { Social } \\
\text { Sciences }\end{array}$ & Humanities & Sci. & Eng. & Sci. & Eng. & Total \\
\hline & $\mathrm{n}=1013$ & $\mathrm{n}=153$ & $\mathrm{n}=153$ & $\mathrm{n}=344$ & $\mathrm{n}=122$ & $\mathrm{n}=103$ & $\mathrm{n}=257$ & $\mathrm{n}=457$ \\
\hline Professional & $21.5 \%$ & $20.9 \%$ & $17.0 \%$ & $22.1 \%$ & $23.8 \%$ & $11.7 \%$ & $11.3 \%$ & $11.1 \%$ \\
\hline Thesis progress & $10.8 \%$ & $9.2 \%$ & $7.8 \%$ & $12.2 \%$ & $13.1 \%$ & $11.7 \%$ & $10.9 \%$ & $11.8 \%$ \\
\hline Personal issues & $3.8 \%$ & $4.6 \%$ & $4.6 \%$ & $4.9 \%$ & $1.6 \%$ & $6.8 \%$ & $3.5 \%$ & $3.9 \%$ \\
\hline Other disagreements & $8.9 \%$ & $11.1 \%$ & $5.9 \%$ & $9.9 \%$ & $8.2 \%$ & $8.7 \%$ & $8.6 \%$ & $8.6 \%$ \\
\hline No disagreements & $52.6 \%$ & $52.9 \%$ & $62.7 \%$ & $48.8 \%$ & $51.6 \%$ & $61.2 \%$ & $64.6 \%$ & $63.9 \%$ \\
\hline Not Specified & $2.4 \%$ & $1.3 \%$ & $2.0 \%$ & $2.0 \%$ & $1.6 \%$ & $0.0 \%$ & $1.2 \%$ & $0.7 \%$ \\
\hline
\end{tabular}

\section{Summary}

It is interesting to point out the considerable difference in patterns of meeting with their adviser in various academic fields. In Israel, $63.9 \%$ of S\&E students meet their adviser every week! And $22.1 \%$ met their adviser bi-weekly. Only $11.6 \%$ of SS\&H students met their adviser weekly. About one third met their adviser once a month and another third only once a semester. In Western Europe, only $43.9 \%$ of S\&E students met their adviser weekly, about $20 \%$ less than in Israel.

Due to the extensive involvement of the adviser, about 51\% of S\&E candidates in Israel answered that the adviser made a major contribution to their research, while this was only about $40 \%$ in Western Europe. In Western Europe, $10 \%$ of the candidates answered that their adviser made no contribution to their work; that is, they worked alone or were advised by a third party. In Israel, $46 \%$ of SS\&H students answered that their adviser made a major contribution to their research.

Some $37-40 \%$ of students who were involved in the survey replied that their adviser had good managerial skills. There are similar patterns in Israel and Western Europe regardless of the academic field.

\section{Experience and Feelings of Doctoral Candidates}

\section{Q14: Which statement best represents your experience as a PhD candidate?}

More than $55 \%$ of the total population of students answered that they worked towards the $\mathrm{PhD}$ while experiencing "highs" and "lows", but eventually they would get the degree (Table 14). Observing Israeli students' answers in Table 14, it was clear that Social Sciences candidates' answers had a different pattern from those of their peers in Humanities and in S\&E. Therefore, we analyzed and separately compared the answers from Social Sciences vs. S\&E as well as Humanities vs. S\&E:

Only $11.26 \%$ of Social Sciences students worked towards the degree experiencing confidence while $22.46 \%$ of S\&E students did so, presenting a significant difference in answer patterns $\left(\mathrm{DF}=1, \chi^{2}=9.033, \mathrm{p}=0.003\right)$. Some $21.77 \%$ of Humanities students experienced confidence during their studies and had no significant difference in the answer patterns, as compared to S\&E students in Israel $\left(\mathrm{DF}=1, \chi^{2}=0.031, \mathrm{p}=0.860\right)$.

Some $24.02 \%$ of S\&E students in Western Europe worked with confidence towards the degree, compared to $22.46 \%$ in Israel; thus no significant difference between the answer patterns in both places $\left(\mathrm{DF}=1, \chi^{2}=0.0273, \mathrm{p}=0.599\right)$. 


\begin{tabular}{|l|c|c|c|c|c|c|c|c|}
\hline \multicolumn{7}{|c|}{ Table 14: Which statement best represents your experience as a PhD candidate? } \\
\hline & \multicolumn{3}{|c|}{ Israel } & \multicolumn{3}{c|}{ Western Europe } \\
\hline & Total & $\begin{array}{c}\text { Social } \\
\text { Sciences }\end{array}$ & Humanities & Sci. & Eng. & Sci. & Eng. & Total \\
\cline { 2 - 10 } & $\mathrm{n}=1013$ & $\mathrm{n}=153$ & $\mathrm{n}=153$ & $\mathrm{n}=344$ & $\mathrm{n}=122$ & $\mathrm{n}=103$ & $\mathrm{n}=257$ & $\mathrm{n}=457$ \\
\hline $\begin{array}{l}\text { I work towards the degree } \\
\text { experiencing significant } \\
\text { uncertainty and concerns }\end{array}$ & $11.9 \%$ & $11.1 \%$ & $11.1 \%$ & $12.2 \%$ & $18.9 \%$ & $20.4 \%$ & $16.3 \%$ & $18.7 \%$ \\
\hline $\begin{array}{l}\text { I work towards the degree } \\
\text { experiencing significant } \\
\text { confidence and satisfac- } \\
\text { tion }\end{array}$ & $21.2 \%$ & $11.1 \%$ & $20.9 \%$ & $20.9 \%$ & $26.2 \%$ & $23.3 \%$ & $24.1 \%$ & $23.3 \%$ \\
\hline $\begin{array}{l}\text { I work towards the degree } \\
\text { experiencing many } \\
\text { "highs" and "lows", but I } \\
\text { will eventually get the } \\
\text { degree }\end{array}$ & $64.9 \%$ & $76.5 \%$ & $64.1 \%$ & $66.0 \%$ & $54.9 \%$ & $56.3 \%$ & $58.8 \%$ & $57.5 \%$ \\
\hline Not Specified & $2.0 \%$ & $1.3 \%$ & $3.9 \%$ & $0.9 \%$ & $0.0 \%$ & $0.0 \%$ & $0.8 \%$ & $0.5 \%$ \\
\hline
\end{tabular}

\section{Q15: Which statement best expresses your feelings as a PhD candidate?}

Observing the answers from the total population of students, $70.3 \%$ of Israeli students answered, "I love my research, and enjoy my life as a $\mathrm{PhD}$ candidate" while only $56.8 \%$ in Western European did so (Table 15). Some $4.96 \%$ of Israeli and $9.75 \%$ of Western European S\&E students answered that they were disappointed with the doctoral program, and that it was below their expectations. Only $4.74 \%$ of Israeli and $6.41 \%$ of Western European S\&E students regretted choosing the doctoral program, but they understood that they had to complete it and get on with their lives.

\begin{tabular}{|l|c|c|c|c|c|c|c|c|}
\hline \multicolumn{7}{|c|}{ Table 15: Which statement best expresses your feelings as a PhD candidate } \\
\hline & \multicolumn{3}{|c|}{ Israel } & \multicolumn{3}{c|}{ Western Europe } \\
\hline & Total & $\begin{array}{c}\text { Social } \\
\text { Sciences }\end{array}$ & Humanities & Sci. & Eng. & Sci. & Eng. & Total \\
\cline { 2 - 12 } & $\mathrm{n}=1013$ & $\mathrm{n}=153$ & $\mathrm{n}=153$ & $\mathrm{n}=344$ & $\mathrm{n}=122$ & $\mathrm{n}=103$ & $\mathrm{n}=257$ & $\mathrm{n}=457$ \\
\hline $\begin{array}{l}\text { I love my research and } \\
\text { enjoy my life as a PhD } \\
\text { candidate }\end{array}$ & $70.3 \%$ & $63.4 \%$ & $73.2 \%$ & $71.5 \%$ & $73.8 \%$ & $60.2 \%$ & $55.6 \%$ & $56.8 \%$ \\
\hline $\begin{array}{l}\text { I have learned a lot but I } \\
\text { do not enjoy my life as a } \\
\text { candidate }\end{array}$ & $20.4 \%$ & $30.7 \%$ & $15.7 \%$ & $17.4 \%$ & $18.9 \%$ & $24.3 \%$ & $27.6 \%$ & $26.0 \%$ \\
\hline $\begin{array}{l}\text { I am disappointed. The } \\
\text { experience is far below } \\
\text { my expectations }\end{array}$ & $4.0 \%$ & $2.0 \%$ & $2.6 \%$ & $5.8 \%$ & $2.5 \%$ & $9.7 \%$ & $9.7 \%$ & $10.3 \%$ \\
\hline $\begin{array}{l}\text { I regret choosing this } \\
\text { path, but now I just have } \\
\text { to complete it and get on } \\
\text { with my life }\end{array}$ & $3.6 \%$ & $2.6 \%$ & $4.6 \%$ & $4.7 \%$ & $4.9 \%$ & $5.8 \%$ & $6.6 \%$ & $6.6 \%$ \\
\hline Not Specified & $1.7 \%$ & $1.3 \%$ & $3.9 \%$ & $0.6 \%$ & $0.0 \%$ & $0.0 \%$ & $0.4 \%$ & $0.2 \%$ \\
\hline
\end{tabular}

We decided to analyze and compare the answer "I have learned a lot, but I do not enjoy my life as a candidate" with the other answers. Here again, we noticed that Social Sciences students answered differently from their colleagues (Table 15); therefore, we analyzed them separately. In Israel, $31.13 \%$ of SS students gave this answer, compared to $17.89 \%$ of S\&E students (DF=1, 
$\left.\chi^{2}=11.976, p=0.0005\right)$. There was a significant difference in the pattern. $16.33 \%$ of Humanities students answered that they learned a lot but did not enjoy the journey compared to S\&E Israeli students' answers. So there was no significant difference between them $\left(\mathrm{DF}=1, \chi^{2}=0.188\right.$, $\mathrm{p}=0.664$ ). In Western Europe, $26.74 \%$ of S\&E students answered, "I have learned a lot, but I do not enjoy my life as a candidate," compared to $17.89 \%$ of Israeli S\&E students; showing a significant difference in the answer pattern $\left(\mathrm{DF}=1, \chi^{2}=9.320, \mathrm{p}=0.002\right)$.

\section{Summary}

The last two questions were aimed at getting feedback about the experience and feelings of doctoral candidates during their studies towards the doctoral degree. $55 \%$ of all candidates reported encountering "highs" and "lows" during their doctoral research; however, they believed that eventually they would get their degree. The majority of students understood that experiencing highs and lows is part of a doctoral project and it was associated with relatively high uncertainty. More candidates experienced confidence while working towards their $\mathrm{PhD}$ than those who experienced uncertainty and concern.

Finally, the students were asked to express their feelings as $\mathrm{PhD}$ candidates. The majority of all candidates replied, "I love my research and enjoy my life as a PhD candidate." In Israel, more SS students experienced concerns and did not enjoy their life as doctoral students compared to their peers in Western Europe. The S\&E students in Israel loved their research and enjoyed life more than their peers in Western Europe did. Fewer Israelis candidates were disappointed with their doctoral program or regretted choosing it.

\section{Discussion}

In our study, doctoral students were surveyed about their opinions regarding their doctoral research project. The survey focused on the following aspects: management skills; adviser-advisee relationship; general information; and the students' experiences and feelings as candidates.

\section{Management Skills}

The term research project is widely used to describe the process of doctoral studies (Lauriol, 2006; Lee, 2008; Pyhältö, Vekkaila, \& Keskinen, 2012). Phillips and Pugh (2010) used several elements of project management to guide students in managing time and tasks and to reduce uncertainty. A risk reduction plan is an additional element of project management. Evans (2004) explains the risks that a doctoral student is facing during the doctoral project. These risks may include failing to achieve research goals, not passing the final examination, or even being preempted by another doctoral student publishing similar scientific results. We could not find references that use project management methodology as a holistic framework for directing a doctoral project.

In our study, analysis of relevant questions revealed that more than $55 \%$ of all candidates understood that doctoral research is a project. However, $95 \%$ of them have never received training in managing a research project. About three quarters reported that they worked on their doctoral research without having an updated plan for it. In practical terms, they neither planned nor executed their research in accordance with a detailed plan. Roughly 3 of every 4 doctoral candidates participating in the survey reported a lack of management skills needed for efficiently completing a doctoral thesis. SS\&H students, who start their doctoral program at an older age, had more managerial experience than the younger S\&E students.

The absence of management skills is a common pattern related to all doctoral candidates, irrespective of their academic field, and is similar among Israeli and Western European candidates. 
All projects - including research projects - have a customer who defines the requirements to be fulfilled (Project Management Institute, 2013). Shenar, Levy, and Dvir (1997) found that the customer has a central role in the success of a research project. While working on a doctoral research project in academia, the only customer is the adviser (Katz, 2009). The adviser defines the academic requirements to be satisfied and has the authority to decide whether the quality of the scientific outcome meets these requirements as well as his or her expectations. The adviser also has the fundamental authority of deciding whether the student is ready to submit his thesis to the doctoral committee and advance to the final examination. The stakeholders in a project are the users of the project's outcome (Alexander, 2005). In a doctoral project, stakeholders may include the university, the department, and the candidate's peers and family. Sometimes, the doctoral candidate does not recognize the adviser's central role, and this may become a potential source for conflicts and disagreements between candidate and adviser.

Based on our analysis of replies to the question, "Who is your customer while working on a doctoral research?" it became obvious that most candidates - regardless of their academic field or of the country where they studied - did not understand the difference between "project customer" and "project stakeholders/users". The majority of all candidates replied that their customers were their academic peers, mistakenly assuming that those who would read the scientific papers published in the wake of a doctoral study were the customers. However, the candidate's peers have no say in defining the doctoral project's requirements, and indeed may never get the chance to read the study's outcome should the real customer, the adviser, decide that the quality of the research is insufficient for graduation. Remarkably, over a quarter of all participants replied that they are the customers of their own research. This prevalent but incorrect answer can be explained by the fact that many candidates regard the effort needed to complete a doctoral thesis as a personal challenge - an intellectual journey that one takes on to show oneself, and the world, that one can make it.

\section{Relations with the Adviser}

The advisory relationship is a major factor of student satisfaction or disappointment in a doctoral program (Ives \& Rowley, 2005). Protivnak and Foss (2009) showed that collaboration between students and faculty members was an important factor for successful completion of doctoral studies. They reported that many students felt that the mentoring they received was the most helpful experience of their doctoral studies; conversely, some students had difficulty with doctoral mentoring and felt abandoned. A survey conducted at two universities in the US showed that advisers' assessment of the extent of their contribution to their students' doctoral research tended to be higher than that of their students (Dong, 1998).

The current study shows that in Israel, the overall majority of students in all four academic fields respected and appreciated their advisers' contribution to their scientific advancement. A higher percentage of students in SS\&H claimed that the adviser did not contribute to their research. Relative to Israeli S\&E students, candidates in Western Europe are less appreciative of their advisers' contribution, with a higher percentage claiming that the adviser contributed nothing at all. Golde and Dore (2001) reported that doctoral students in the US were overwhelmingly pleased with their adviser; asked whether they "have the adviser they want", 59.1\% strongly agreed and $32.2 \%$ disagreed. These findings represent a higher rate of satisfaction with the adviser than the current study yielded both for Israel and for Western Europe.

Our survey revealed a considerable difference in the frequency of adviser-advisee meetings, which is much higher among S\&E students than among SS\&H students. This can be explained by the different nature of research in "hard sciences" and, consequently, the required involvement of the advisers in students' projects. In "soft sciences", the student works more individually and independently and probably cannot present substantial advancement on a weekly basis. In Israel, 
$63.9 \%$ of S\&E students met their adviser every week - about $20 \%$ higher than the rate among Western European students. This phenomenon may be explained by the different nature of S\&E doctoral programs in Israel and Europe. In Israel, the doctoral program follows the American system where research projects are closely directed by the adviser. In Western Europe, many doctoral projects are performed within research institutions or in industry; therefore, the adviser's involvement may be lesser than in cases where the student works in the adviser's laboratory. Either way, we believe that it is the adviser's responsibility to meet with students on a regular basis and control their advancement.

Golde and Dore (2001) asked doctoral candidates in the US for responses on the statement: "I am satisfied with the amount and quality of time spent with my adviser." $32.5 \%$ of the candidates disagreed or strongly disagreed with this statement - 39.2\% in Art History and only $23.3 \%$ in Mathematics. Another question in the survey was, "How much time could you expect to spend with your adviser?" Only $22.5 \%$ said they were "very clear" about the amount of time that they could actually expect to spend with their adviser, while a third of them reported being "not clear at all" about it. When sorted by fields of research, the four fields where candidates reported the least clarity on this subject were all in Humanities, while Science students reported higher levels. The trends reported in this study in the US were in general agreement with our findings regarding Israel and Western Europe.

\section{General Information}

Becher (1994) discussed disciplinary differences within universities. Universities are composed of different "tribes", each with a distinct name, territory, language, and symbols. These potential differences in traditions between various doctoral programs motivated us to compare the opinions of candidates from different academic disciplines. The general features observed among doctoral candidates from four academic disciplines in Israel are as follows. Engineering and Sciences candidates started their doctorate programs at a younger age than their peers in SS\&H and mainly as full-time candidates. They spent more time per week on research. Their interest in becoming lecturers or professors was lower than their peers in SS\&H. These substantial differences may be explained by the nature of "hard sciences", which are more demanding and require continuity in studies, leading S\&E students to start the program at a younger age as full-time students and spend more time on research. SS\&H students tended to leave school at some point and return later, after several years of work experience. Therefore, more of them studied as part-time external students (about 33\%) and devoted less time to research. Gardner and Gopaul (2012) showed that students who were in part-time cohort programs described a different experience from some of the few who pursued their degrees on a part-time basis feeling alone. The cohort students felt they knew that their peers and faculty understood their needs. Those students outside the cohort experience said they encountered many obstacles to making their part-time status more manageable. Following Gardner and Gopaul's definition, part-time S\&E students (who were a minority in their program) may be regarded as "some of the few", while part-time candidates in SS\&H may be regarded as "cohort" students

Comparing the general features of Israeli S\&E students and their peers in Western Europe, the Israeli students started the doctoral program, on average, at a significantly older age, due to mandatory military service. In other parameters, the patterns in Israel and Western Europe are quite similar. The interest of S\&E candidates in becoming professors in academia is significantly lower than that of their colleagues in SS\&H. This may be explained by the competitive hi-tech market that offers high-quality jobs to $\mathrm{S} \& \mathrm{E} \mathrm{PhD}$ graduates, which are at least as attractive and rewarding as positions in academia. 


\section{Experience and Feelings}

As to the candidates' experiences, the patterns among all candidates were quite similar. The majority (more than 60\%) of all students experienced "highs" and "lows" during their doctoral journey, but believed that this path would eventually lead them to earn their degree. Therefore, it seems that this "bumpy road" pattern best represents the nature of doctoral research. Holbrook et al. (2014) conducted a study which examined the expectations vs. experiences of Australian doctoral candidates. The study quotes a number of candidates who had expected that their emotional journey during the research process might resemble a 'roller-coaster', but did not foresee the intensity they actually experienced. According to this reference, the students experienced what we called "highs" and "lows" in a manner similar to our findings.

As to candidates' feelings during the doctoral journey, the majority of students replied that they loved their research and enjoyed their life as $\mathrm{PhD}$ candidates. Israeli $\mathrm{S} \& \mathrm{E}$ students expressed more positive feelings towards the doctoral program than their peers in Western Europe. As reported earlier, Israeli S\&E students met their adviser more often and enjoyed more interaction with their advisers and greater involvement thereof. This fact alone may be a reason for their positive feelings, in agreement with findings reported by Ives and Rowley (2005).

\section{Conclusions}

The current study's most significant conclusion is related to the lack of management skills among doctoral candidates, regardless of their chosen academic field or whether their university is located in Israel or Western Europe. The majority of all candidates understand that a doctoral research is a project, but have never been trained to manage a research project. Thus, the majority set out to work on their doctoral project without planning or controlling their research advancement. We conclude that there is a need to at least propose project management training in some form to all doctoral candidates. Unlike the hi-tech scientific industry, which regularly applies project management methods, the academic world has not yet accepted project management tools as a resource for managing doctoral research. Training students in basic project management techniques is relatively simple, requiring only a short course which can be conducted as a one- or two-day workshop. This novel finding is the main contribution of this study to the advancement of doctoral education.

Another conclusion is that the majority of enrolled candidates appreciated their advisers' contribution to the advancement of their doctoral program. Good interaction with the advisers leads to satisfaction and a positive research experience. This finding is in agreement with published literature. A majority of students experienced "highs" and "lows" during the doctoral journey, but believed that eventually they would attain their degree. We can conclude that the "bumpy road" pattern best represents the typical advancement of a doctoral project that includes many unpredicted, unique, and original challenges.

About two thirds of all students reported that they loved their research and enjoyed their life as doctoral candidates. This can be interpreted as a natural and expected reaction by young and healthy adults working on challenging research. Yet a question remains: Why did so many students - about one third - state that they do not enjoy their life as candidates, feel disappointed, and even regret choosing doctoral studies? This finding raises another question: How can we, the educators, improve this situation?

Improving doctoral education is a continuous challenge that educators and administrators share. In this study we focused on the managerial aspects needed for better conducting a doctoral research project. Scientific projects which are conducted in research institutions or in industry regularly apply tools for project management and control. Academia, which relies on traditions that slowly evolved over decades and even centuries, is slower in adopting changes and modern 
methods. We hope the results of our study will initiate a discussion as well as further studies that will lead to a necessary change.

\section{Acknowledgments}

I would like to acknowledge the assistance of Prof. Ayala Cohen and Dr. Tatiana Umansky, as well as Olga Polovinets.

\section{References}

Alexander, I. F. (2005). A taxonomy of stakeholders: Human roles in system development. International Journal of Technology and Human Interaction, 1(1), 23-59.

Becher, T. (1994). The significance of disciplinary differences. Studies in Higher Education, 19(2), 151161.

Cardinal, L. B. (2001). Technological innovation in the pharmaceutical industry: The use of organizational control in managing research and development. Organization Science, 12(1), 19-36.

Delamont, S., Parry, O., \& Atkinson, P. (1998). Creating delicate balance: The doctoral supervisor's dilemmas. Teaching in Higher Education, 3(2), 157-163.

Dong, Y. R. (1998). Non-native graduate students' thesis/dissertation writing in science: Self-reports by students and their advisors from two U.S. institutions. English for Specific Purposes, 17(4), 369-390.

Evans, T. (2004). Risky doctorates: Managing doctoral studies in Australia as managing risk. AARE 2004 International Education Research conference proceedings. Retrieved from: http://www.aare.edu.au/data/publications/2004/eva04264.pdf

Gardner, S. K. (2008). What's too much and what's too little? The process of becoming an independent researcher in doctoral education. The Journal of Higher Education, 79, 326-350.

Gardner, S.K. (2010). Contrasting the socialization experiences of doctoral students in high- and lowcompleting departments: A qualitative analysis of disciplinary contexts at one institution. The Journal of Higher Education, 81(1), 61-81.

Gardner, S. K., \& Gopaul, B. (2012). The part-time doctoral student experience. International Journal of Doctoral Studies, 7, 63-78. Retrieved from http://ijds.org/Volume7/IJDSv7p063-078Gardner352.pdf

Gatfield, T. (2005). An investigation into PhD supervisory management styles: Development of a dynamic conceptual model and its managerial implications. Journal of Higher Education Policy and Management, 27(3), 311-325.

Golde, C. M., \& Dore, T. M. (2001). At cross purposes: What the experiences of today's doctoral students reveal about doctoral education. Madison, WI: University of Wisconsin at Madison. ERIC Number: ED450628.

Graves, N. J., \& Varma, V. P. (1998). Working for a doctorate: A guide for the humanities and social sciences. New York: Routledge.

Grover, V. (2007). Successfully navigating the stages of doctoral study. International Journal of Doctoral Studies, 2, 10-21. Retrieved from http://www.ijds.org/Volume2/IJDSv2p009-021Grover21.pdf

Grover, V., \& Thatcher, J. B. (2010). The 10 mistakes students make in their doctoral program revisited: The student response (Part one). Decision Line, 41(2), 15-19.

Holbrook, A., Shaw, K., Scevak, J., Bourke, S., Cantwell, R., \& Budd, J. (2014). PhD candidate expectations: Exploring mismatch with experience. International Journal of Doctoral Studies, 9, 329-346. Retrieved from http://ijds.org/Volume9/IJDSv9p329-346Holbrook0575.pdf

Ives, G., \& Rowley, G. (2005). Supervisor selection or allocation and continuity of supervision: Ph.D. students' progress and outcomes. Studies in Higher Education, 30(5), 535-555. 
Jairam, D., \& Kahl, D. H., Jr. (2012). Navigating the doctoral experience: The role of social support in successful degree completion. International Journal of Doctoral Studies, 7, 311-329. Retrieved from http://ijds.org/Volume7/IJDSv7p311-329Jairam0369.pdf

Jones, M. (2013). Issues in doctoral studies - forty years of journal discussion: Where have we been and where are we going? International Journal of Doctoral Studies, 8, 83-104. Retrieved from http://ijds.org/Volume8/IJDSv8p083-104JonesFT129.pdf

Katz, R. (2009). Shorten the time to doctorate: A guide to managing a Ph.D. as a project. Bloomington, IN: AuthorHouse.

Lauriol, J. (2006). Proposals for designing and controlling a doctoral research project in management sciences. The Electronic Journal of Business Research Methods, 4(1), 31-38.

Lee, A. (2008). How are doctoral students supervised? Concepts of doctoral research supervision. Studies in Higher Education, 33(3), 267-281.

Lovitts, B. E. (2001). Leaving the ivory tower: The causes and consequences of departure from doctoral study. Rowman \& Littlefield.

Lovitts, B. E. \& Nelson, C. (2000). The hidden crisis in graduate education: Attrition from Ph.D. programs. Academe, 6(6), 44-50.

Mason, M. M. (2012). Motivation, satisfaction, and innate psychological needs. International Journal of Doctoral Studies, 7, 259-277. Retrieved from http://ijds.org/Volume7/IJDSv7p259-277Mason0345.pdf

McWilliam, E., Singh, P., \& Taylor, P. G. (2002). Doctoral education, danger and risk management. Higher Education Research and Development. 21(2), 119-130.

Phillips, E. M., \& Pugh, D. S. (2010). How to get a PhD (5th ed.). Berkshire, England: Open University Press, McGraw Hill Education.

Project Management Institute. (2013). A Guide to the project management body of knowledge: PMBOK Guide (5th ed.) Project Management Institute.

Protivnak, J. J., \& Foss, L. L. (2009). An exploration of themes that influence the counselor education doctoral student experience. Counselor Education and Supervision, 48(4), 239 - 256.

Pyhältö, K., Vekkaila, J., \& Keskinen, J. (2012). Exploring the fit between doctoral students' and supervisors' perceptions of resources and challenges vis-à-vis the doctoral journey. International Journal of Doctoral Studies, 7, 395-414. Retrieved from http://ijds.org/Volume7/IJDSv7p395-414Pyhalto383.pdf

Shenhar, A. J., Levy, O., \& Dvir, D. (1997). Mapping the dimensions of project success. Project Management Institute, 28(2), 5-13.

Zhao, C. M., Golde, C. M., \& McCormick, A. C. (2007). More than a signature: How adviser choice and adviser behavior affect doctoral student satisfaction. Journal of Further and Higher Education, 31(3), 263-281.

\section{Biography}

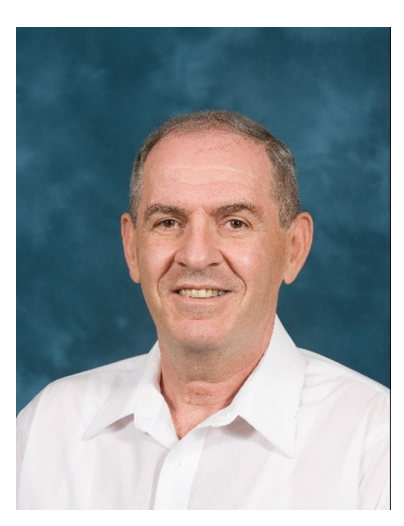

Reuven Katz is an Associate Professor of Mechanical Engineering and of Education in Science and Technology at the Technion, Israel Institute of Technology. He is the director of the Center for Manufacturing Systems and Robotics and the director of the graduate program for Design and Manufacturing Management at the Technion. He received his $\mathrm{BSc}$ and MSc degrees in Mechanical Engineering from the Technion, $\mathrm{PhD}$ degree in Mechanical Engineering from the University of Michigan, Ann Arbor and an MBA degree from the University of Tel Aviv. 